\title{
Invited review: Contemporary environmental issues: A review of the dairy industry's role in climate change and air quality and the potential of mitigation through improved production efficiency
}

\author{
S. E. Place and F. M. Mitloehner ${ }^{1}$ \\ Department of Animal Science, University of California, Davis, One Shields Ave., Davis 95616-8521
}

\begin{abstract}
Environmental concerns involving the dairy industry are shifting from an exclusive focus on water quality to encompass climate change and air quality issues. The dairy industry's climate change air emissions of concern are the greenhouse gases methane and nitrous oxide. With regard to air quality, the dairy industry's major emission contributions are particulate matter, volatile organic compounds, and ammonia. The emissions of these compounds from dairies can be variable because of a number of factors including weather conditions, animal type, management, and nutrition. To evaluate and compare emissions across the diverse operations that comprise the US dairy industry, emissions should be reported per unit of output (e.g., per $\mathrm{kg}$ of $3.5 \%$ fatcorrected milk). Accurately modeling emissions with models that can predict the complex bio-geochemical processes responsible for emissions is critical to assess current emissions inventories and develop mitigation strategies. Improving the dairy industry's production efficiency (e.g., improvements in management, nutrition, reproduction, and cow comfort) is an effective way to reduce emissions per unit of milk. With accurate process-based models, emissions reductions due to improved production efficiency could be reported per unit of milk and predicted on a farm-to-farm basis.
\end{abstract}

Key words: dairy cattle, air quality, climate change

\section{INTRODUCTION}

Environmental concerns involving the US dairy industry have historically focused on nutrient management issues affecting water quality. Recently, growing concern about global climate change and air quality has spurred evaluations of dairy's contribution; however, the complexity and variation in dairy production systems make the quantification of greenhouse gas (GHG) and other

Received September 10, 2009.

Accepted April 1, 2010.

${ }^{1}$ Corresponding author: fmmitloehner@ucdavis.edu air quality-related emissions difficult. Several recent articles have used life cycle assessments (LCA) that employ "cradle-to-grave" accounting of GHG from inputs and outputs over the entire meat or milk production chain (Casey and Holden, 2005; Steinfeld et al., 2006; Capper et al., 2009). The application and comparisons across these existing LCA can be limited because of differences in scope and scale (Pitesky et al., 2009). Reporting emissions per unit of production (e.g., per $\mathrm{kg}$ of $3.5 \% \mathrm{FCM}$ ) can clarify some of the discrepancies. To evaluate US dairy production systems accurately, so-called process-based models that can predict the complex bio-geochemical processes involved throughout the dairy product life cycle are needed and are being developed. A full review of air emissions from US dairy production or a complete review of current US air emissions regulations is beyond the scope of this review. This work identifies the main areas of concern for the dairy industry with regard to air quality and climate change, followed by a discussion of the importance of mitigation through production efficiency in minimizing dairy's environmental impact.

\section{CLIMATE CHANGE}

Climate can be described as long-term average weather that is, in part, determined by the greenhouse effect (IPCC, 2007). The greenhouse effect refers to the process where long-wave radiation released from the Earth's surface as a result of the absorption of solar radiation is partially trapped by GHG, thereby warming the lower atmosphere. The greenhouse effect allows the average surface temperature of the Earth to be $14^{\circ} \mathrm{C}$, whereas, without the greenhouse effect, the global mean surface temperature would be $-19^{\circ} \mathrm{C}$ (IPCC, 2007). The Earth's climate has continuously changed throughout its $\sim 4.5$-billion-year history; however, recent warming changes are influenced by human activities that increase the atmospheric concentration of GHG (IPCC, 2007; US EPA, 2009a). Anthropogenic (human-caused) emissions of GHG have increased since the beginning of the Industrial Revolution (c. 1750) 
and further increases are likely as worldwide fossil fuel combustion continues to rise. The anthropogenic GHG of greatest concern are carbon dioxide $\left(\mathrm{CO}_{2}\right)$, methane $\left(\mathrm{CH}_{4}\right)$, and nitrous oxide $\left(\mathrm{N}_{2} \mathrm{O}\right)$. These gases have different potentials for trapping heat in the Earth's atmosphere known as global warming potentials (GWP); thus, emissions of $\mathrm{CH}_{4}$ and $\mathrm{N}_{2} \mathrm{O}$ are often reported in $\mathrm{CO}_{2}$-equivalents (IPCC, 2007). The Intergovernmental Panel on Climate Change (IPCC) Fourth Assessment Report estimates the 100-yr GWP of $\mathrm{CH}_{4}$ and $\mathrm{N}_{2} \mathrm{O}$ to be 21 and 310 times greater than that of $\mathrm{CO}_{2}$, respectively (IPCC, 2007).

Currently (August 2009), the United States neither requires mandatory reporting nor regulates total GHG emissions. At the state level, California became the first state to regulate and mandate reporting of GHG emissions with Assembly Bill 32 (California Global Warming Solutions Act of 2006). This bill does not exempt GHG emissions from the agriculture sector. As California legislation often sets precedents for other states' legislation as well as federal legislation, the dairy industry should focus on quantifying its GHG emissions and finding strategies to reduce emissions.

\section{Carbon Dioxide}

The anthropogenic GHG contributing most to climate change, $\mathrm{CO}_{2}$, is a byproduct of aerobic cellular respiration and fossil fuel combustion (IPCC, 2007). The $\mathrm{CO}_{2}$ emitted from the respiration of dairy animals is not considered a net contributor to climate change because the animals consume plants that use $\mathrm{CO}_{2}$ during photosynthesis (Steinfeld et al., 2006). However, $\mathrm{CO}_{2}$ emitted by modern dairy production from fossil fuel combustion for on-farm use, transportation, and electricity generation has been considered a net source of GHG in several LCA (Casey and Holden, 2005; Steinfeld et al., 2006; Capper et al., 2009) and whole-farm emissions models (Schils et al., 2007).

\section{Methane}

Methane emissions from dairies can originate from enteric fermentation in the digestive tracts of cattle or from stored waste. Enteric $\mathrm{CH}_{4}$ emissions result from rumen methanogens utilizing $\mathrm{CO}_{2}$ and hydrogen gas (byproducts of feed fermentation by bacteria, fungi, and protozoa) to produce $\mathrm{CH}_{4}$ (Janssen and Kirs, 2008). Hydrogen can be toxic to certain bacteria; therefore, methanogens play a necessary role in maintaining a healthy rumen environment (Beauchemin et al., 2009b). However, $\mathrm{CH}_{4}$ emissions from dairy animals represent a gaseous loss of their dietary energy intake (Moe and Tyrrell, 1979). Most $\mathrm{CH}_{4}$ is produced in the rumen and released through eructation, although approximately $13 \%$ of methanogenesis can occur in the large intestine (Ellis et al., 2008). The amount of $\mathrm{CH}_{4}$ emitted per animal varies widely because of numerous factors, including DMI, the amount and type of dietary carbohydrate, forage processing and quality, dietary lipids, and the addition of feed additives that can alter rumen microbial populations (Moe and Tyrrell, 1979; Johnson and Johnson, 1995). Because of the myriad factors influencing its production, $\mathrm{CH}_{4}$ can represent energy losses varying from 2 to $12 \%$ of gross energy intake (Johnson and Johnson, 1995). Recent work measuring emissions from dairy cattle and their fresh waste in an environmentally controlled chamber demonstrated that most $\mathrm{CH}_{4}$ originates from the animal, not from the fresh manure (Sun et al., 2008a). However, compared with fresh waste, long-term manure storage is a more significant source of $\mathrm{CH}_{4}$ emissions. The amount of $\mathrm{CH}_{4}$ produced by stored manure depends on the amount of $\mathrm{C}, \mathrm{H}$, and $\mathrm{O}_{2}$ present; therefore, diet, bedding, and manure management greatly influence $\mathrm{CH}_{4}$ emissions from manure slurry (Kulling et al., 2003; Amon et al., 2006). Land-applied manure produces limited amounts of $\mathrm{CH}_{4}$ because methanogenesis is an anaerobic process, thus the manure's exposure to air halts its progress (Chadwick et al., 2000).

\section{Nitrous Oxide}

Nitrous oxide is a highly volatile GHG that is formed through microbial processes during denitrification of nitrate $\left(\mathrm{NO}_{3}\right)$ to nitrogen gas $\left(\mathrm{N}_{2}\right)$. Major sources of $\mathrm{N}_{2} \mathrm{O}$ on dairy farms are long-term manure storage lagoons and emissions from cropland fertilized with $\mathrm{N}$ fertilizer or manure (Velthof et al., 1998; de Boer, 2003). Small amounts of $\mathrm{N}_{2} \mathrm{O}$ result from $\mathrm{NO}_{3}$ reduction processes in the rumen (Kaspar and Tiedje, 1981), although emissions of $\mathrm{N}_{2} \mathrm{O}$ directly from the cow are not usually considered in analyses of dairy emissions (Casey and Holden, 2005). Reducing $\mathrm{N}_{2} \mathrm{O}$ emissions can have a large impact on the overall GHG emissions from dairies because of the high GWP of $\mathrm{N}_{2} \mathrm{O}$ (IPCC, 2007).

\section{AIR QUALITY}

Air quality affects human and animal respiratory health, ecosystem health, and visibility (Pope et al., 2009; Cambra-López et al., 2010). The US Environmental Protection Agency (EPA) has set National Ambient Air Quality Standards for the US as mandated by the Clean Air Act. These standards regulate levels of 6 pollutants: carbon monoxide $(\mathrm{CO})$, lead $(\mathrm{Pb})$, nitrogen dioxide $\left(\mathrm{NO}_{2}\right)$, particulate matter $(\mathbf{P M})$ less than $10 \mu \mathrm{m}$ in diameter $\left(\mathrm{PM}_{10}\right)$, $\mathrm{PM}$ less than $2.5 \mu \mathrm{m}$ in 


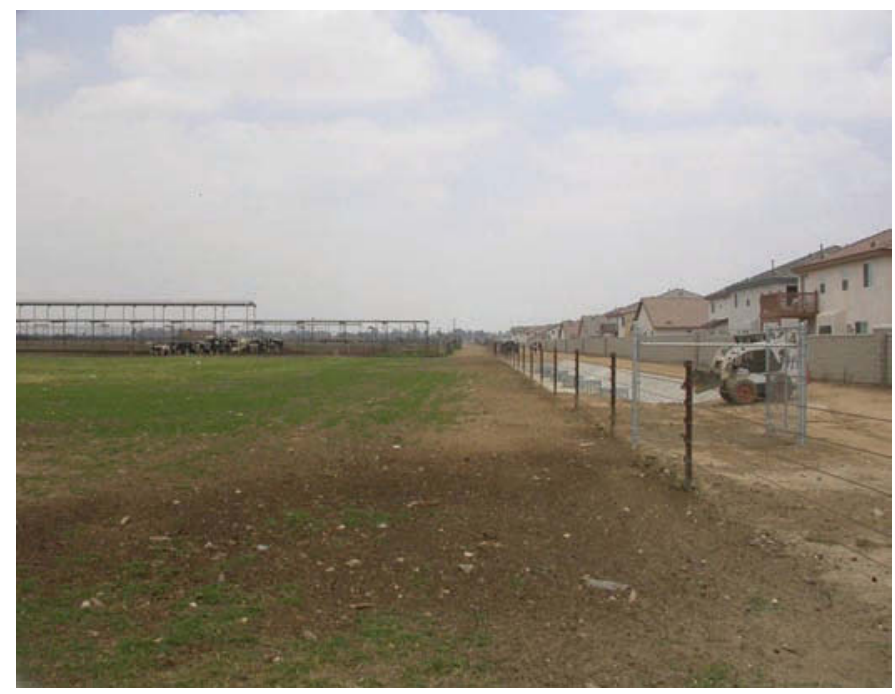

Figure 1. Urban residential encroachment on a dairy in Southern California.

diameter $\left(\mathrm{PM}_{2.5}\right)$, ozone $\left(\mathrm{O}_{3}\right)$, and sulfur dioxide $\left(\mathrm{SO}_{2}\right)$ (US EPA, 2009b). The EPA's primary standards are meant to address direct public health concerns and the secondary standards are in place to protect general public welfare (e.g., visibility and environmental effects; US EPA, 2008). The dairy industry contributes to air pollution by emissions from animals, cropping systems, feed management, and waste. The major air pollutants of concern from dairies are PM, ammonia $\left(\mathrm{NH}_{3}\right)$, and volatile organic compounds (VOC). Currently, there are no federal standards regulating dairy $\mathrm{NH}_{3}$ and VOC atmospheric emissions directly, but $\mathrm{NH}_{3}$ can contribute to PM formation (Pinder et al., 2007) and VOC contribute to $\mathrm{O}_{3}$ formation (Sun et al., 2008b; US EPA, 2008).

An issue of growing concern to the dairy industry is nuisance-related lawsuits. Recently, in several US states, dairy producers have been litigated for nuisance issues by encroaching on residential communities (similar to those depicted in Figure 1) for dust, odors, and flies.

\section{Particulate Matter}

In 2007, 73.4 million people were living in US counties exceeding the EPA primary standard for $\mathrm{PM}_{2.5}$, whereas 13 million lived in counties exceeding the standard for $\mathrm{PM}_{10}$ (US EPA, 2008). Epidemiological studies have demonstrated an association between reduced life expectancy and increasing levels of $\mathrm{PM}_{2.5}$ (Pope et al., 2009). Coarse PM (10 $\mu \mathrm{m}$ or less in diameter) sourced from dairies and instilled into mouse lungs has been shown to elicit an inflammatory response (Wegesser and Last, 2009; Wegesser et al., 2010). In addition to their negative health effects, PM can contribute to impaired atmospheric visibility by scattering and absorbing light (Boylan et al., 2006). The PM emissions from dairies can result from dairy cattle locomotion in drylot corrals (Rogge et al., 2006), tillage and harvesting activities for feed production (Baker et al., 2005), and indirectly by the formation of PM complexes with $\mathrm{NH}_{3}$ as a precursor (Pinder et al., 2007).

\section{Ammonia}

Ammonia emissions from dairies can contribute to human respiratory health problems (Pinder et al., 2007), decreased livestock performance (Drummond et al., 1980), and eutrophication and acidification of aquatic ecosystems (Fangmeier et al., 1994; Krupa, 2003). Fresh manure, long-term manure storage, and land application of manure are the main sources of $\mathrm{NH}_{3}$ emissions from dairies (Bussink and Oenema, 1998). As ruminants, dairy cattle have the unique ability to recycle $\mathrm{N}$ back to rumen bacteria that would otherwise be excreted as urinary urea-N. Urinary urea-N is strongly correlated with rumen $\mathrm{N}$ losses and increasing dietary CP (James et al., 1999). The limits of the ability of dairy animals to recycle $\mathrm{N}$ are rarely reached in commercial US herds; thus, excess dietary CP leads to high urine urea-N content (Marini and Van Amburgh, 2005). Urea- $\mathrm{N}$ from urine combined with feces containing urease leads to $\mathrm{NH}_{3}$ formation (Sun et al., 2008b). As the $\mathrm{N}$ content of the feces is quite constant, $\mathrm{NH}_{3}$ emissions from fresh manure in dairy facilities depend on the urinary urea- $\mathrm{N}$ content and the degree of mixing between feces and urine (Bussink and Oenema, 1998). Consequently, great variations in $\mathrm{NH}_{3}$ emissions from farm to farm exist, depending on diet (VandeHaar and St-Pierre, 2006) and manure management, along with manure land-application method (Amon et al., 2006) and time of year (Bussink and Oenema, 1998).

\section{Volatile Organic Compounds}

Volatile organic compounds are a large class of chemicals that contribute to $\mathrm{O}_{3}$ formation when combined with oxides of nitrogen $\left(\mathrm{NO}_{\mathrm{x}}\right)$ and sunlight (Shaw et al., 2007). Volatile organic compounds vary greatly in their reactivity and relative contribution to $\mathrm{O}_{3}$ formation (Carter, 1994). Shaw et al. (2007) investigated VOC emissions from both lactating and dry dairy cows and their fresh waste. These workers found that the VOC observed with the highest emission fluxes had $\mathrm{O}_{3}$ formation potentials much smaller per VOC molecule than most natural biogenic and anthropogenic combustion-derived VOC (Shaw et al., 2007). Recent work has shown that the most significant dairy VOC 
emission sources are from silage and silage-containing TMR rather than from stored manure as was previously assumed by most US agencies (Howard et al., 2010a,b). Alanis et al. (2008) sampled silage and TMR from one dairy and found that VFA contributed the greatest proportion of the feedstuffs' total VOC emissions. However, dairies emit a wide range of VOC that can vary in concentration by season (Filipy et al., 2006; Montes et al., 2010). Thus, further research is needed to quantify the amount, the sources, and the factors influencing the variability of VOC emissions across dairies.

\section{MITIGATION}

The world population is expected to grow from 6.8 billion persons in 2009 to 9.1 billion in 2050 (United Nations, 2009). With no prospects to significantly increase the amount of arable agricultural land, food production must intensify to ensure an affordable, abundant food supply. Therefore, emissions mitigation strategies need to balance environmental concerns with the growing global demand for dairy products, along with financial viability to individual dairy producers. Mitigation of dairy emissions can be separated into 2 approaches: directly reducing emissions from known sources or reducing life-cycle emissions on a per-unit-of-output basis through improvements in production efficiency. Currently, few strategies exist to quantifiably reduce direct emissions from dairy operations (e.g., covering manure storage lagoons and measuring captured or flared $\mathrm{CH}_{4}$ ). Reductions in direct emissions cannot be easily quantified or standardized across all dairies because the dairy industry includes both intensive, confined operations and extensive, grazing-based operations. The disparities between and within the facilities and management of large dairies and their traditional, small, tie-stall counterparts are great. Because of the dearth of direct emission reduction strategies and variability across farms, the following sections will focus on how improving production efficiency reduces emissions per unit of milk.

\section{Production Efficiency}

Production efficiency in the dairy industry can be defined as minimizing the amount of inputs (e.g., feed, fossil fuels) and outputs (e.g., $\mathrm{NH}_{3}, \mathrm{GHG}$ ) to produce a given quantity of milk. Production efficiency improvements can come from minimizing waste, maximizing a dairy cow's milk production, and maximizing the proportion of her life spent in peak milk production without sacrificing animal health and well-being. To a degree, when milk production per cow is improved, the life-cycle emissions of dairy production decrease per unit of milk (i.e., per kg of 3.5\% FCM; VandeHaar and St-Pierre; 2006). This is achieved through a dilution of maintenance costs per kilogram of FCM at the level of both the individual cow and the entire US dairy production system. Cows that produce more milk reduce the proportion of total consumed feedstuffs going toward maintenance energy costs (Moe and Tyrell, 1975; Bauman et al., 1985; VandeHaar, 1998). Secondarily, more milk per cow can decrease the total lactating herd size needed to produce a given quantity of milk (Capper et al., 2008, 2009). Past improvements demonstrate the ability of production efficiency to decrease the environmental impact per unit of milk. Capper et al. (2009) found that historical advances in genetics, nutrition, and management of dairy farms allowed dairy production in 2007 to emit $43 \%$ of the $\mathrm{CH}_{4}$ and $56 \%$ of the $\mathrm{N}_{2} \mathrm{O}$ that were emitted in 1944 to produce one billion kilograms of milk. As the following sections demonstrate, more opportunities for improving a dairy's production efficiency exist that could lead to further reductions in emissions per kilogram of FCM.

Heifer Management. Replacement heifers are an important part of the life-cycle emissions of a kilogram of FCM. Before calving, heifers are consuming inputs and producing both GHG and air pollutants without contributing to the production of milk. In the milk-fed stage of a heifer's life, she can efficiently convert consumed energy and protein into lean body tissue without depending on emission-producing rumen microbes. Recent research has found that increasing and altering the nutrients supplied to milk-fed calves can improve growth rates and feed efficiency (Brown et al., 2005; Bascom et al., 2007; Hill et al., 2008). "Intensified" feeding programs for dairy heifers have been shown to lower age at first calving (Raeth-Knight et al. 2009), with no reduction (Van Amburgh et al., 1998) or even an improvement in first-lactation milk yield (Drackley et al., 2007). Both decreasing the current national average age at first calving of $25.2 \mathrm{mo}$ (USDA, 2007) and increasing first-lactation milk yield could improve milk's life-cycle production efficiency and decrease emissions per kilogram of FCM.

Colostrum administration is another aspect of heifer management that can affect GHG and air quality emissions per kilogram of FCM. Dairy calves depend on passive immunization from the absorption of antibodies in colostrum to provide adequate immunity during their early life stages (Robison et al., 1988). Failure of passive transfer of immunity leads to increased mortality and morbidity and decreased growth performance (Robison et al., 1988; Beam et al., 2009). Administering the proper quantity of high quality colostrum within the first few hours of life has been shown to improve long-term animal health and first-lactation performance 
(DeNise et al., 1989; Faber et al., 2005). Beam et al. (2009) estimated that failure of passive transfer occurs in $19.2 \%$ of US dairy heifer calves; therefore, decreasing this incidence could substantially decrease death and performance losses and lessen emissions per kilogram of FCM.

Herd Health. Herd-health challenges affect per-unitof-milk emissions by increasing mortality and losses of saleable milk and decreasing reproductive performance and milk production efficiency. Herd health is influenced by many factors, including management, nutrition, the environment, and social stressors. Over the past $25 \mathrm{yr}$, the dairy industry has steadily shifted its structure toward fewer farms with larger herds and fewer workers per cow. In 2008, 3,350 US dairy farms with 500 or more cows (approximately $5 \%$ of total dairy operations) produced $58.5 \%$ of the nation's milk with $54.9 \%$ of the nation's dairy cows (NASS, 2009). Along with the industry's consolidation, milk production per cow has doubled over the past $25 \mathrm{yr}$, although it appears that disease incidence has remained stable (LeBlanc et al., 2006). However, the productive life of Holsteins in the United States born in 2000 decreased by 3.95 mo compared with Holstein cows born in 1980 (Dechow and Goodling, 2008). Thus, opportunities exist for the dairy industry to advance production efficiency by improving herd health to simultaneously enhance milk production, reproductive performance, and cow longevity.

When dairy cattle transition from a pregnant, nonlactating state to a lactating state, they face a tremendous change in their metabolic requirements (e.g., Ca requirements are estimated to increase 4 -fold on the day of parturition; Overton and Waldron, 2004). Consequently, most health concerns arise during the transition period. Approximately $75 \%$ of disease occurs within the first month after calving (LeBlanc et al., 2006), and a study of Pennsylvania dairy herds found that $26.2 \%$ of dairy culls occur from $21 \mathrm{~d}$ before to $60 \mathrm{~d}$ after calving (Dechow and Goodling, 2008). Recent research has linked disease incidence and excessive negative energy balances during the transition period with significant decreases in milk yield and reproductive success during the subsequent lactation (Drackley, 1999). Further research into the biology and management of transition cows and the extension of this critical knowledge to commercial herds can enhance the life-cycle efficiency of the US dairy production system.

Environmental or social stressors can decrease the production efficiency of the cow and subsequently increase the emissions of each kilogram of milk that she produces. Heat stress has been estimated to cost the dairy industry nearly $\$ 1$ billion per year in decreased milk production, reproductive performance, and increased death losses (St-Pierre et al., 2003).
With regard to social stress, grouping animals according to size and age and minimizing overcrowding can improve DMI, consequentially improving milk production (Grant and Albright, 2001). Improving cow cooling during hot summer months and grouping animals to minimize behavioral stress has been the focus of research to improve farm profitability, but these improvements have the potential to decrease emissions per kilogram of FCM as well.

Mastitis is a herd-health challenge that can affect emissions per kilogram of FCM by decreasing milk production performance and increasing losses of saleable milk. Hospido and Sonesson (2005) analyzed the environmental impact of mastitis using an LCA of dairy herds in Galicia, Spain. The authors found that decreasing the clinical mastitis rate from 25 to $18 \%$ and the subclinical mastitis rate from 33 to $15 \%$ reduced the GWP of a unit of milk by $2.5 \%$ (Hospido and Sonesson, 2005) because of increased input-use efficiency, decreased losses of milk production, and a decreased amount of waste milk.

Lameness is a critical herd-health concern that seems to have worsened over the past $25 \mathrm{yr}$ (LeBlanc et al., 2006). Lameness or injury is responsible for approximately $20 \%$ of mortalities and $16 \%$ of selective culls in mature US dairy cows (USDA, 2007). In addition to decreased survivability, lameness causes decreased milk production (Warnick et al., 2001) and poorer reproductive performance in affected cows (Garbarino et al., 2004). Improved facilities, management, nutrition, and genetics all have the potential to decrease the incidence of lameness (Baird et al., 2009) and decrease emissions per kilogram of FCM.

Nutrition and Feed Production. The nutrition of dairy cattle greatly determines the emissions produced directly by the ruminant animal and its waste. Diet composition can alter rumen fermentation to reduce the amount of $\mathrm{CH}_{4}$ produced (Ellis et al., 2008) and, as previously discussed, the $\mathrm{NH}_{3}$ emissions produced from the manure (James et al., 1999; VandeHaar and St-Pierre, 2006). The substrates used by methanogens are byproducts of structural carbohydrate fermentation; thus, high concentrate diets containing more nonstructural carbohydrates can lead to decreased $\mathrm{CH}_{4}$ emissions (Lana et al., 1998; Ellis et al., 2008). However, diets very high in concentrate (such as those fed to the majority of US beef feedlot cattle) can decrease rumen $\mathrm{pH}$ and lead to rumen acidosis (Owens et al., 1998). Furthermore, very high concentrate diets diminish the principal environmental benefit of dairy cows: their ability to convert cellulose, indigestible to humans and the Earth's most abundant organic molecule, into high-quality proteins for human consumption (Oltjen and Beckett, 1996). Therefore, the $\mathrm{CH}_{4}$ produced by 
dairy cattle cannot simply be seen as a gross energy loss and GHG source but is a necessary consequence of transforming inedible fibrous forages and byproducts (e.g., almond hulls, citrus pulp, distillers grains) into food and fiber products fit for human use. Nonetheless, substantial reductions in $\mathrm{CH}_{4}$ emissions can be achieved without feeding high levels of concentrates by altering the previously mentioned nutritional factors: microbial-altering feed additives, dietary lipids, and forage processing and quality (Johnson and Johnson, 1995).

Feed additives, such as the ionophore monensin, can change microbial processes in the rumen to potentially improve feed efficiency and reduce $\mathrm{CH}_{4}$ emissions (Tedeschi et al., 2003). However, research with monensin has shown conflicting results (Guan et al., 2006; Odongo et al., 2007; Hamilton et al, 2009; Hook et al., 2009), which suggests a need for more in-depth research on its effect on rumen microbial populations and the metabolism of dairy cows. Alternatives to ionophores such as probiotics (e.g., yeast), essential oils, and biologically active plant compounds (e.g., condensed tannins) have shown promise for $\mathrm{CH}_{4}$ reductions; however, most research to date has been conducted in vitro and more in vivo studies are needed to evaluate the effect of these alternatives on $\mathrm{CH}_{4}$ and their commercial viability (Calsamiglia et al., 2007; Beauchemin et al., 2009b).

Dietary lipids, specifically unsaturated fatty acids, have the potential to act as an alternate $\mathrm{H}$ sink in the rumen, thereby reducing the $\mathrm{H}$ available to methanogens and the $\mathrm{CH}_{4}$ produced (Ellis et al., 2008). Additionally, $\mathrm{CH}_{4}$ reductions from feeding dietary lipids can be attributed to their suppression of fiber-digesting bacteria and toxicity to protozoa closely associated with methanogens (Hristov et al., 2009). Johnson et al. (2002) tested the ability of canola and whole cottonseed to reduce $\mathrm{CH}_{4}$ and found no difference in emissions when compared with a control diet, whereas other researchers have found crushed canola seed to have a $\mathrm{CH}_{4}$-suppressing effect (Beauchemin et al., 2009a). The inconsistency of the effect of dietary lipids on $\mathrm{CH}_{4}$ is due, in part, to the variation in diets, the fatty acid profile, amount and form of the lipid source, and the length of the feeding trial, because the rumen ecosystem may adapt to lipid supplementation (Martin et al., 2008; Beauchemin et al., 2009a). Although lipids do have the potential to reduce $\mathrm{CH}_{4}$ emissions, consideration must be given to their adverse side effects of reducing DMI or decreasing milk fat when fed at levels over a critical threshold (Giger-Reverdin et al., 2003; Martin et al., 2008). Furthermore, the source and availability of lipids must be considered, because price will dictate their commercial adoption, and long-distance transport of lipid sources may defeat their emission-reducing potential by increasing fossil fuel combustion.

Forage quality and management can affect both air quality and GHG emissions per kilogram of FCM. Fermented feeds are a major source of VOC (Alanis et al., 2008) and require substantial fossil fuel inputs during their production (de Boer, 2003; Schils et al., 2007); therefore, minimizing dry matter loss throughout the production, storage, and feeding of these feedstuffs will decrease the air quality and climate change impact of each kilogram of feed. Higher quality forages, produced by ideal crop production, harvesting, and preservation practices, maximize DMI and milk production (Oba and Allen, 1999). Additionally, forages with higher digestibility and higher rates of passage out of the rumen have the potential to reduce enteric $\mathrm{CH}_{4}$ emissions for each unit of feed consumed (Johnson and Johnson, 1995).

So-called precision feeding that closely matches the nutrients needed by the dairy cow for maintenance, growth, lactation, and gestation to the supplied dietary nutrients can minimize the environmental impact of the cow's excreta (Tylutki et al., 2008). Precision feeding requires nutritional models with sufficient accuracy and a level of management that can reduce the feeding system's variation (Wang et al., 2000). By constantly monitoring the dry matter and nutrient composition of feedstuffs, dairy producers can avoid expensive overfeeding and minimize nutrient excretion that can lead to emissions. The potential reduction in $\mathrm{NH}_{3}$ emissions by more tightly managing the $\mathrm{CP}$ content of the diet to match the animal's needs is substantial because most of the $\mathrm{N}$ fed over requirements is excreted as urinary urea-N. Castillo et al. (2001) found that cows with intakes of $419 \mathrm{~g}$ of $\mathrm{N} / \mathrm{d}$ had similar milk production as cows consuming $516 \mathrm{~g}$ of N/d; however, $74 \%$ of the extra $94 \mathrm{~g}$ of $\mathrm{N} / \mathrm{d}$ was excreted as urinary urea-N, which could be lost to the environment as $\mathrm{NH}_{3}$ emissions. Moreover, a precision feeding strategy decreases the amount of refusals, which may become waste on a dairy or be fed to other production groups (e.g., lactating cow refusals fed to heifers) that have dissimilar nutrient needs, thereby increasing the likelihood for higher nutrient excretion (St-Pierre and Thraen, 1999). Additionally, closely monitoring and ensuring the correct nutrition of individual groups of animals can minimize the risk of other nutritionally influenced diseases and conditions, such as ketosis, lameness, and prolonged anestrous (Lucy, 2001; Roche, 2006). Overall, managing feed and feeding programs to minimize waste while maximizing milk production can improve farm profitability and decrease the life-cycle emissions per kilogram of FCM.

Reproduction. Perhaps not as apparent as nutrition, reproductive performance greatly affects emissions 
per kilogram of FCM. Dairy cows that have extended calving intervals because of conception failure spend more time out of peak milk when feed conversion into milk is most efficient. The total productive lifetime of many dairy cows is determined by reproductive performance, because reproductive problems are responsible for $26.3 \%$ of the selective culls in the United States (USDA, 2007). Over the past $30 \mathrm{yr}$, the reproductive performance and productive lifetime of dairy cattle have substantially decreased while milk production has increased (Lucy, 2001; Dechow and Goodling, 2008). The negative effect per kilogram of FCM emissions caused by declining reproductive efficiency has likely been offset by increases in milk production per cow. However, restoring reproductive performance in combination with increased milk yield would further reduce emissions per kilogram of FCM. Garnsworthy (2004) modeled the environmental impact of reproductive performance and milk production in the United Kingdom. The model found that both higher milk yield and improved reproductive performance (better estrus detection and conception rates) contributed to reduced $\mathrm{CH}_{4}$ and $\mathrm{NH}_{3}$ emissions because of the smaller lactating and replacement herd population required to meet UK production quotas (Garnsworthy, 2004). The cause of the decline in reproductive efficiency of dairy cattle is multifaceted and is not completely understood currently (Ingvartsen et al., 2003), because reproductive success is influenced by nutrition, genetics, health disorders during transition, management, and the environment (Lucy, 2001). The level of reproductive success across all US herds is variable by region, breed, and management (Norman et al., 2009), suggesting that improvements are achievable. Encouragingly, recent data show that the long-term trend of decreasing reproductive performance and survivability may be slowing or reversing (Hare et al., 2006; Norman et al., 2009). Extensive research in dairy cattle reproduction is needed to identify the factors impeding fertility and to further develop strategies to improve reproduction on commercial herds. Wide adoption of these successful reproductive strategies could potentially lengthen the productive life of the US dairy cow and lower emissions per kilogram of FCM.

Sexed semen is a reproductive technology that has the potential to both help and hurt the impact of the dairy industry on air quality and climate change per kilogram of FCM. If used selectively, sexed semen can increase the rate of genetic gain in dairy cattle, allowing advantageous traits to become ubiquitous in the entire dairy cattle population (De Vries et al., 2008). Furthermore, on average, heifer calves are smaller than bull calves and cause fewer dystocias, which may allow for earlier breeding of heifers, and fewer mortalities and health problems (Weigel, 2004). However, if all animals are bred with sexed semen (or even all heifers), the replacement population for the US dairy herd will increase in size. To keep the total population of dairy cattle at a level that does not create an oversupply of milk, the lactating cow cull rate must increase. Again, this can be advantageous, because poor performing animals and those with poor genetic merit would likely be culled, but in the context of environmental impact per kilogram of FCM, the widespread use of sexed semen could increase emissions per kilogram of FCM by shortening the total productive lifetime of dairy cows. Furthermore, a larger replacement herd size means more nonproductive emissions for each kilogram of FCM produced.

\section{MODELING LIFE CYCLE EMISSIONS OF THE DAIRY INDUSTRY}

One of the greatest challenges to determining and mitigating emissions with accuracy and precision is integrating the complexity of the nutrient flows on the scale of a single dairy farm. The variability across the genetics, facilities, management, nutrition, feed production, and reproductive performance of all US dairy herds makes assigning a single emission factor an inaccurate method to determine US dairy emissions. An analysis of all factors and a determination of their impact in the whole-farm system can best be achieved through sophisticated, mechanistic process-based computer models (NRC, 2003). A thorough description or comparison of existing rumen and environmental models is beyond the scope of this review but is available in many recent publications (Fox et al., 2004; Kebreab et al., 2004; Offner and Sauvant, 2004; Dijkstra et al., 2007; Schils et al., 2007; Ellis et al., 2008; Johnson and Baldwin, 2008; Kebreab et al., 2008; Tylutki et al., 2008; Capper et al., 2009). Many of the current efforts in mechanistic emissions modeling focus exclusively on nutrition, with limited ability to incorporate management, reproduction, disease, genetics, or environmental conditions. These mechanistic models (e.g., Molly) can more accurately predict ruminal $\mathrm{CH}_{4}$ emissions over a variety of diets compared with empirical models based on simple regression equations (e.g., Moe and Tyrrell, 1979; Benchaar et al., 1998). However, most current models that attempt to predict emissions and nutrient flows at the dairy farm level are only partially mechanistic or wholly empirical (Schils et al., 2007). A dynamic mechanistic model that can integrate many factors (e.g., management, nutrition, reproduction, weather) in its emissions predictions will be necessary to accurately estimate current US dairy emissions and develop strategies to reduce emissions. The best mitigation strategy to reduce the life cycle emissions of a kilo- 
gram of FCM while optimizing business sustainability and animal welfare will likely vary from farm to farm; thus, process-based models will be crucial if air quality and climate change emissions from dairies are regulated nationally. However, a comprehensive, collaborative scientific research effort is needed to better understand the emissions and nutrient flows in the dairy production system, as well as the actual development of an all-encompassing process-based model. Such an effort would require cooperation of expertise across multiple disciplines and institutions to organize research toward a single model's development.

\section{CONCLUSIONS}

The US dairy production system contributes to air pollution and global climate change but also serves as a critical supplier of nutritious food. As historical observations have shown, improving production efficiency is an effective method to reduce emissions per unit of milk while concurrently improving dairy farm profitability. With a process-based model, a holistic analysis of the dairy food production system is possible, and mitigation strategies could be developed to reduce air emissions per unit of output. A thorough scientific understanding of climate change and air quality impacts of the dairy industry, taking into account its historical progress for context, would best serve the world's simultaneous needs for safe, high-quality dairy products and environmental stewardship.

\section{REFERENCES}

Alanis, P., M. Sorenson, M. Beene, C. Krauter, B. Shamp, and A. S. Hasson. 2008. Measurement of non-enteric emission fluxes of volatile fatty acids from a California dairy by solid phase microextraction with gas chromatography/mass spectrometry. Atmos. Environ. 42:6417-6424.

Amon, B., V. Kryvoruchko, T. Amon, and S. Zechmeister-Boltenstern. 2006. Methane, nitrous oxide and ammonia emissions during storage and after application of dairy cattle slurry and influence of slurry treatment. Agric. Ecosyst. Environ. 112:153-162.

Baird, L. G., N. E. O'Connell, M. A. McCoy, T. W. J. Keady, and D. J. Kilpatrick. 2009. Effects of breed and production system on lameness parameters in dairy cattle. J. Dairy Sci. 92:2174-2182.

Baker, J. B., R. J. Southard, and J. P. Mitchell. 2005. Agricultural dust production in standard and conservation tillage systems in the San Joaquin Valley. J. Environ. Qual. 34:1260-1269.

Bascom, S. A., R. E. James, M. L. McGilliard, and M. E. Van Amburgh. 2007. Influence of dietary fat and protein on body composition of Jersey bull calves. J. Dairy Sci. 90:5600-5609.

Bauman, D. E., S. N. McCutcheon, W. D. Steinhour, P. J. Eppard, and S. J. Sechen. 1985. Sources of variation and prospects for improvement of productive efficiency in the dairy cow: A review. J. Anim. Sci. 60:583-592.

Beam, A. L., J. E. Lombard, C. A. Kopral, L. P. Garber, A. L. Winter, J. A. Hicks, and J. L. Schlater. 2009. Prevalence of failure of passive transfer of immunity in newborn heifer calves and associated management practices on US dairy operations. J. Dairy Sci. 92:3973-3980.
Beauchemin, K. A., T. A. McAllister, and S. M. McGinn. 2009b. Dietary mitigation of enteric methane from cattle. CAB Reviews: Perspectives in Agriculture, Veterinary Science . Nutr. Nat. Resour. 35:1-18.

Beauchemin, K. A., S. M. McGinn, C. Benchaar, and L. Holtshausen. 2009a. Crushed sunflower, flax, or canola seeds in lactating dairy cow diets: Effects on methane production, rumen fermentation, and milk production. J. Dairy Sci. 92:2118-2127.

Benchaar, C., J. Rivest, C. Pomar, and J. Chiquette. 1998. Prediction of methane production from dairy cows using existing mechanistic and regression equations. J. Anim. Sci. 76:617-627.

Boylan, J. W., M. T. Odman, J. G. Wilkinson, and A. G. Russell. 2006. Integrated assessment modeling of atmospheric pollutants in the southern Appalachian Mountrains: part II. Fine particulate matter and visibility. J. Air Waste Manage. Assoc. 56:12-22.

Brown, E. G., M. J. VandeHaar, K. M. Daniels, J. S. Liesman, L. T. Chapin, D. H. Keisler, and M. S. Weber Nielsen. 2005. Effect of increasing energy and protein intake on body growth and carcass composition of heifer calves. J. Dairy Sci. 88:585-594.

Bussink, D. W., and O. Oenema. 1998. Ammonia volatilization from dairy farming systems in temperate areas: A review. Nutr. Cycl. Agroecosyst. 51:19-33.

Calsamiglia, S., M. Busquet, P. W. Cardozo, L. Castillejos, and A. Ferret. 2007. Invited review: Essential oils as modifiers of rumen microbial fermentation. J. Dairy Sci. 90:2580-2595.

Cambra-López, M., A. J. A. Aarnink, Y. Zhao, S. Calvet, and A. G. Torres. 2010. Airborne particular matter from livestock production systems: A review of an air pollution problem. Environ. Pollut. 158:1-17.

Capper, J. L., R. A. Cady, and D. E. Bauman. 2009. The environmental impact of dairy production: 1944 compared with 2007. J. Anim. Sci. 87:2160-2167.

Capper, J. L., E. Castaneda-Gutierrez, R. A. Cady, and D. E. Bauman. 2008. The environmental impact of recombinant bovine somatotropin (rbST) use in dairy production. Proc. Natl. Acad. Sci. USA 105:9668-9673.

Carter, W. P. L. 1994. Development of ozone reactivity scales for volatile organic compounds. J. Air Waste Manage. 44:881-899.

Casey, J. W., and N. M. Holden. 2005. Analysis of greenhouse gas emissions from the average Irish milk production system. Agric. Syst. 86:97-114.

Castillo, A. R., E. Kebreab, D. E. Beever, J. H. Barbi, J. D. Sutton, H. C. Kirby, and J. France. 2001. The effect of protein supplementation of nitrogen utilization in lactating dairy cows fed grass silage diets. J. Anim. Sci. 79:247-253.

Chadwick, D. R., B. F. Pain, and S. K. E. Brookman. 2000. Nitrous oxide and methane emissions following application of animal manures to grassland. J. Environ. Qual. 29:277-287.

de Boer, I. J. M. 2003. Environmental impact assessment of conventional and organic milk production. Livest. Prod. Sci. 80:69-77.

De Vries, A., M. Overton, J. Fetrow, K. Leslie, S. Eicker, and G. Rodgers. 2008. Exploring the impact of sexed semen on the structure of the dairy industry. J. Dairy Sci. 91:847-856.

Dechow, C. D., and R. C. Goodling. 2008. Mortality, culling by sixty days in milk, and production profiles in high- and low-survival Pennsylvania herds. J. Dairy Sci. 91:4630-4639.

DeNise, S. K., J. D. Robison, G. H. Stott, and D. V. Armstrong. 1989. Effects of passive immunity on subsequent production in dairy heifers. J. Dairy Sci. 72:552-554.

Dijkstra, J., E. Kebreab, J. A. N. Mills, W. F. Pellikaan, S. López, A. Bannink, and J. France. 2007. Predicting the profile of nutrients available for absorption: From nutrient requirement to animal response and environmental impact. Animal 1:99-111.

Drackley, J. K. 1999. Biology of dairy cows during the transition period: The final frontier? J. Dairy Sci. 82:2259-2273.

Drackley, J. K., B. C. Pollard, H. M. Dann, and J. A. Stamey. 2007. First-lactation milk production for cows fed control or intensified milk replacer programs as calves. J. Dairy Sci. 90(Suppl. 1):779. (Abstr.) 
Drummond, J. G., S. E. Curtis, J. S. Simon, and H. W. Norton. 1980. Effects of aerial ammonia on growth and health of young pigs. J. Anim. Sci. 50:1085-1091.

Ellis, J. L., J. Dijkstra, E. Kebreab, A. Bannink, N. E. Odongo, B. W. McBride, and J. France. 2008. Aspects of rumen microbiology central to mechanistic modeling of methane production in cattle. J. Agric. Sci. 146:213-233.

Faber, S. N., N. E. Faber, T. C. McCauley, and R. L. Ax. 2005. Case study: Effects of colostrum ingestion on lactation performance. Prof. Anim. Sci. 21:420-425.

Fangmeier, A., A. L. Hadwiger-Fangmeier, L. Van der Eerden, and H. J. Jäger. 1994. Effects of atmospheric ammonia on vegetation-A review. Environ. Pollut. 86:43-82.

Filipy, J., B. Rumburg, G. Mount, H. Westberg, and B. Lamb. 2006. Identification and quantification of volatile organic compounds from a dairy. Atmos. Environ. 40:1480-1494.

Fox, D. G., L. O. Tedeschi, T. P. Tylutki, J. B. Russell, M. E. Van Amburgh, L. E. Chase, A. N. Pell, and T. R. Overton. 2004. The Cornell Net Carbohydrate and Protein System model for evaluating herd nutrition and nutrient excretion. Anim. Feed Sci. Technol. 112:29-78.

Garbarino, E. J., J. A. Hernandez, J. K. Shearer, C. A. Risco, and W. W. Thatcher. 2004. Effects of lameness on ovarian activity in postpartum Holstein cows. J. Dairy Sci. 87:4123-4131.

Garnsworthy, P. C. 2004. The environmental impact of fertility in dairy cows: A modeling approach to predict methane and ammonia emissions. Anim. Feed Sci. Technol. 112:211-223.

Giger-Reverdin, S., P. Morand-Fehr, and G. Tran. 2003. Literature survey of the influence of dietary fat composition on methane production in dairy cattle. Livest. Prod. Sci. 82:73-79.

Grant, R. J., and J. L. Albright. 2001. Effect of animal grouping on feeding behavior and intake of dairy cattle. J. Dairy Sci. 84(E Suppl.):E156-E163.

Guan, H., K. M. Wittenberg, K. H. Ominski, and D. O. Krause. 2006. Efficacy of ionophores in cattle diets for mitigation of enteric methane. J. Anim. Sci. 84:1896-1906.

Hamilton, S. W., E. J. DePeters, J. A. McGarvey, J. Lathrop, and F. M. Mitloehner. 2009. Greenhouse gas, animal performance, and bacterial population structure responses to dietary monensin fed to dairy cows. J. Environ. Qual. 39:106-114.

Hare, E., H. D. Norman, and J. R. Wright. 2006. Survival rates and productive herd life of dairy cattle in the United States. J. Dairy Sci. 89:3713-3720.

Hill, S. R., K. F. Knowlton, K. M. Daniels, R. E. James, R. E. Pearson, A. V. Capuco, and R. M. Akers. 2008. Effects of milk replacer composition on growth, body composition, and nutrient excretion in preweaned Holstein heifers. J. Dairy Sci. 91:3145-3155.

Hook, S. E., K. S. Northwood, A.-D. G. Wright, and B. W. McBride. 2009. Long-term monensin supplementation does not significantly affect quantity or diversity of methanogens in the rumen of lactation dairy cattle. Appl. Environ. Microbiol. 75:374-380.

Hospido, A., and U. Sonesson. 2005. The environmental impact of mastitis: A case study of dairy herds. Sci. Total Environ. 343:7182.

Howard, C. J., A. Kumar, I. A. Malkina, F. M. Mitloehner, P. G. Green, R. Flocchini, and M. J. Kleeman. 2010a. Reactive organic gas emissions from livestock feed contribute significantly to ozone production in central California. Environ. Sci. Technol. 44:23092314.

Howard, C. J., A. Kumar, F. M. Mitloehner, K. R. Stackhouse, P. G. Green, R. G. Flocchini, and M. J. Kleeman. 2010b. Direct measurements of the ozone forming potential from livestock and poultry waste emissions. Environ. Sci. Technol. 44: 2292-2298.

Hristov, A. N., M. Vander Pol, M. Agle, S. Zaman, C. Schneider, P. Ndegwa, V. K. Vaddella, K. Johnson, K. J. Shingfield, and S. K. R. Karnati. 2009. Effect of lauric acid and coconut oil on ruminal fermentation, digestion, ammonia losses from manure, and milk fatty acid composition in lactating cows. J. Dairy Sci. 92:55615582 .

Ingvartsen, K. L., R. J. Dewhurst, and N. C. Friggens. 2003. On the relationship between lactational performance and health: Is it yield or metabolic imbalance that cause production diseases in dairy cattle? A position paper. Livest. Prod. Sci. 83:277-308.

IPCC. 2007. Climate change 2007: The physical life science basis. Group I contribution to the fourth assessment report of the IPCC. Cambridge University Press. Cambridge, UK.

James, T., D. Meyer, E. Esparza, E. J. DePeters, and H. PerezMonti. 1999. Effects of dietary nitrogen manipulation on ammonia volatilization from manure from Holstein heifers. J. Dairy Sci 82:2430-2439.

Janssen, P. H., and M. Kirs. 2008. Structure of the archaeal community of the rumen. Appl. Environ. Microbiol. 74:3619-3625.

Johnson, H. A., and R. L. Baldwin. 2008. Evaluating model predictions of partitioning nitrogen excretion using the dairy cow model Molly. Anim. Feed Sci. Technol. 143:104-126.

Johnson, K. A., and D. E. Johnson. 1995. Methane emissions from cattle. J. Anim. Sci. 73:2483-2492.

Johnson, K. A., R. L. Kincaid, H. H. Westberg, C. T. Gaskins, B. K. Lamb, and J. D. Cronrath. 2002. The effect of oilseeds in diets of lactating cows on milk production and methane emissions. J. Dairy Sci. 85:1509-1515.

Kaspar, H. F., and J. M. Tiedje. 1981. Dissimilatory reduction of nitrate and nitrite in the bovine rumen: Nitrous oxide production and effect of acetylene. Appl. Environ. Microbiol. 41:705-709.

Kebreab, E., K. A. Johnson, S. L. Archibeque, D. Pape, and T. Wirth. 2008. Model for estimating enteric methane emissions from United States dairy and feedlot cattle. J. Anim. Sci. 86:2738-2748.

Kebreab, E., J. A. N. Mills, L. A. Crompton, A. Bannink, J. Dijkstra, W. J. J. Gerrits, and J. France. 2004. An integrated mathematical model to evaluate nutrient partition in dairy cattle between the animal and its environment. Anim. Feed Sci. Technol. 112:131154.

Krupa, S. V. 2003. Effects of atmospheric ammonia $\left(\mathrm{NH}_{3}\right)$ on terrestrial vegetation: a review. Environ. Pollut. 124:179-221.

Kulling, D. R., H. Menzi, F. Sutter, P. Lischer, and M. Kreuzer. 2003. Ammonia, nitrous oxide and methane emissions from differently stored dairy manure derived from grass- and hay-based rations. Nutr. Cycl. Agroecosyst. 65:13-22.

Lana, R. P., J. B. Russell, and M. E. Van Amburgh. 1998. The role of $\mathrm{pH}$ in regulating ruminal methane and ammonia. J. Anim. Sci. 76:2190-2196.

LeBlanc, S. J., K. D. Lissemore, D. F. Kelton, T. F. Duffield, and K. E. Leslie. 2006. Major advances in disease prevention in dairy cattle. J. Dairy Sci. 89:1267-1279.

Lucy, M. C. 2001. Reproductive loss in high-producing dairy cattle: Where will it end? J. Dairy Sci. 84:1277-1293.

Marini, J. C., and M. E. Van Amburgh. 2005. Partition of nitrogen excretion in urine and the feces of Holstein replacement heifers. J. Dairy Sci. 88:1778-1784.

Martin, C., J. Rouel, J. P. Jouany, M. Doreau, and Y. Chilliard. 2008. Methane output and diet digestibility in response to feeding dairy cows crude linseed, extruded linseed, or linseed oil. J. Anim. Sci. $86: 2642-2650$

Moe, P. W., and H. F. Tyrrell. 1975. Efficiency of conversion of digested energy to milk. J. Dairy Sci. 58:602-610.

Moe, P. W., and H. F. Tyrrell. 1979. Methane production in dairy cows. J. Dairy Sci. 62:1583-1586.

Montes, F., S. D. Hafner, C. A. Rotz, and F. M. Mitloehner. 2010 Temperature and air velocity effects on ethanol emission from corn silage with the characteristics of an exposed silo face. Atmos. Environ. 44:1987-1995.

NASS. 2009. Farms, land in farms, and livestock operations: 2008 summary. http://usda.mannlib.cornell.edu/usda/current/ FarmLandIn/FarmLandIn-02-12-2009.pdf Accessed Aug. 23, 2009.

NRC. 2003. Air Emissions from Animal Feeding Operations: Current Knowledge, Future Needs. Natl. Acad. Press, Washington, DC.

Norman, H. D., J. R. Wright, S. M. Hubbard, R. H. Miller, and J. L. Hutchison. 2009. Reproductive status of Holstein and Jersey cows in the United States. J. Dairy Sci. 92:3517-3528.

Oba, M., and M. S. Allen. 1999. Evaluation of the importance of the digestibility of neutral detergent fiber from forage: Effects on 
dry matter intake and milk yield of dairy cows. J. Dairy Sci. 82:589-596.

Odongo, N. E., R. Bagg, G. Vessie, P. Dick, M. M. Or-Rashid, S. E. Hook, J. T. Gray, E. Kebreab, J. France, and B. W. McBride. 2007. Long-term effects of feeding monensin on methane production in lactating dairy cows. J. Dairy Sci. 90:1781-1788.

Offner, A., and D. Sauvant. 2004. Comparative evaluation of the Molly, CNCPS, and LES rumen models. Anim. Feed Sci. Technol. 112:107-130.

Oltjen, J. W., and J. L. Beckett. 1996. Role of ruminant livestock in sustainable agricultural systems. J. Anim. Sci. 74:1406-1409.

Overton, T. R., and M. R. Waldron. 2004. Nutritional management of transition dairy cows: Strategies to optimize metabolic health. J. Dairy Sci. 87(E Suppl.):E105-E119.

Owens, F. N., D. S. Secrist, W. J. Hill, and D. R. Gill. 1998. Acidosis in cattle: A review. J. Anim. Sci. 76:275-286.

Pinder, R. W., P. J. Adams, and S. N. Pandis. 2007. Ammonia emission controls as a cost-effective strategy for reducing atmospheric particulate matter in the eastern United States. Environ. Sci. Technol. 41:380-386.

Pitesky, M. E., K. R. Stackhouse, and F. M. Mitloehner. 2009. Clearing the air: Livestock's contribution to climate change. Adv. Agron. $103: 1-40$

Pope, C. A. III, M. Ezzati, and D. W. Dockery. 2009. Fine-particulate air pollution and life expectancy in the United States. N. Engl. J. Med. 360:376-386.

Raeth-Knight, M., H. Chester-Jones, S. Hayes, J. Linn, R. Larson, D. Ziegler, B. Ziegler, and N. Broadwater. 2009. Impact of conventional or intensive milk replacer programs on Holstein heifer performance through six months of age and during first lactation. J. Dairy Sci. 92:799-809.

Robison, J. D., G. H. Stott, and S. K. DeNise. 1988. Effects of passive immunity on growth and survival in the dairy heifer. J. Dairy Sci. $71: 1283-1287$

Roche, J. F. 2006. The effect of nutritional management of the dairy cow on reproductive efficiency. Anim. Reprod. Sci. 96:282-296.

Rogge, W. F., P. M. Medeiros, and B. R. T. Simoneit. 2006. Organic marker compounds for surface soil and fugitive dust from open lot dairies and cattle feedlots. Atmos. Environ. 40:27-49.

Schils, R. L. M., J. E. Olesen, A. del Prado, and J. F. Soussana. 2007. A review of farm level modeling approaches for mitigating greenhouse gas emissions from ruminant livestock systems. Livest. Sci. 112:240-251.

Shaw, S. L., F. M. Mitloehner, W. Jackson, E. J. DePeters, J. G. Fadel, P. H. Robinson, R. Holzinger, and A. H. Goldstein. 2007. Volatile organic compound emissions from dairy cows and their waste as measured by proton-transfer-reaction mass spectrometry. Environ. Sci. Technol. 41:1310-1316.

St-Pierre, N.R., B. Cobanov, and G. Schnitkey. 2003. Economic losses from heat stress by US livestock industries. J. Dairy Sci. 86(E Suppl.):E52-E77.

St-Pierre, N. R., and C. S. Thraen. 1999. Animal grouping strategies, sources of variation, and economic factors affecting nutrient balance on dairy farms. J. Anim. Sci. 77:72-83.

Steinfeld, H., P. Gerber, T. Wassenaar, V. Castel, M. Rosales, and C. de Haan. 2006. Livestock's long shadow - Environmental issues and options. Food and Agriculture Organization of the United Nations, Rome, Italy.

Sun, H., Y. Pan, Y. Zhao, W. A. Jackson, L. M. Nuckles, I. L. Malkina, V. E. Arteaga, and F. M. Mitloehner. 2008b. Effects of sodium bisulfate on alcohol, amine, and ammonia emissions from dairy slurry. J. Environ. Qual. 37:608-614.
Sun, H., S. L. Trabue, K. Scoggin, W. A. Jackson, Y. Pan, Y. Zhao, I. L. Malkina, J. A. Koziel, and F. M. Mitloehner. 2008a. Alcohol, volatile fatty acid, phenol, and methane emissions from dairy cows and fresh manure. J. Environ. Qual. 37:615-622.

Tedeschi, L. O., D. G. Fox, and T. T. Tylutki. 2003. Potential environmental benefits of ionophores in ruminant. J. Environ. Qual. 32:1591-1602.

Tylutki, T. P., D. G. Fox, V. M. Durbal, L. O. Tedeschi, J. B. Russell, M. E. Van Amburgh, T. R. Overton, L. E. Chase, and A. N Pell. 2008. Cornell net carbohydrate and protein system: A model for precision feeding of dairy cattle. Anim. Feed Sci. Technol. 143:174-202.

United Nations. 2009. World population prospects: The 2008 revision highlights. UN Dept. Econom. Soc. Aff.: Pop. Div., New York, NY. http://www.un.org/esa/population/publications/wpp2008/ wpp2008_highlights.pdf Accessed Aug. 27, 2009.

US EPA. 2008. National air quality: Status and trends through 2007 US Environ. Protection Agency, Washington, DC. http://www. epa.gov/air/airtrends/2008/report/TrendsReportfull.pdf Accessed August 17, 2009

US EPA. 2009a. Inventory of U.S. greenhouse gas emissions and sinks: 1990-2007. US Environ. Protection Agency, Washington, DC. http://epa.gov/climatechange/emissions/usinventoryreport.html Accessed May 15, 2009.

US EPA. 2009b. National ambient air quality standards (NAAQS). US Environ. Protection Agency, Washington, DC. http://epa.gov/air/ criteria.html Accessed August 16, 2009.

USDA. 2007. Dairy 2007, part I: Reference of dairy cattle health and management practices in the United States, 2007. \#N480.1007. USDA-APHIS-VS, CEAH, Fort Collins, CO.

Van Amburgh, M. E., D. M. Galton, D. E. Bauman, R. W. Everett, D. G. Fox, L. E. Chase, and H. N. Erb. 1998. Effects of three prepubertal body growth rates on performance of Holstein heifers during first lactation. J. Dairy Sci. 81:527-538.

VandeHaar, M. J. 1998. Efficiency of nutrient use and relationship to profitability on dairy farms. J. Dairy Sci. 81:272-282.

VandeHaar, M. J., and N. St-Pierre. 2006. Major advances in nutrition: Relevance to the sustainability of the dairy industry. J. Dairy Sci. 89:1280-1291.

Velthof, G. L., M. L. van Beusichem, and O. Oenema. 1998. Mitigation of nitrous oxide emission from dairy systems. Environ. Pollut. 102:173-178.

Wang, S. J., D. G. Fox, D. J. R. Cherney, L. E. Chase, and L. O. Tedeschi. 2000. Whole-herd optimization with the Cornell net carbohydrate and protein system. II. Allocating homegrown feeds across the herd for optimum nutrient use. J. Dairy Sci. 83:21492159.

Warnick, L. D., D. Janssen, C. L. Guard, and Y. T. Gröhn. 2001. The effect of lameness on milk production in dairy cows. J. Dairy Sci 84:1988-1997.

Wegesser, T. C., L. M. Franzi, F. M. Mitloehner, A. Eiguren-Fernandez, and J. A. Last. 2010. Lung antioxidant and cytokine responses to coarse and fine particulate matter from the great California wildfires of 2008. Inhal. Toxicol. 22:561-570.

Wegesser, T. C., and J. A. Last. 2009. Mouse lung inflammation after instillation of particulate matter collected from a working dairy barn. Toxicol. Appl. Pharmacol. 236:348-357.

Weigel, K.A. 2004. Exploring the role of sexed semen in dairy production systems. J. Dairy Sci. 87(E Suppl.):E120-E130. 